\title{
Recoper
}

Breathing life into the revolution.

\section{Neal Asher}

When the stealth boat rose on its hydrofoils, the wind and spray kept me cool in the bright African sun. I gazed back and saw that the Eugov gunboat had finally given up the chase.

Jansen grinned at me. "We're in Moroccan territory now."

Memtech initiated the first recoper in 2044, the year the National Health Police seized a 1,000-tonne shipment of Argentinian beefburgers and subsequently smashed the notorious Midlands fried-food ring, which was led, as government-approved blogs delighted in telling us, by the 'Yorkshire Chipper'. At this time my wife, Gillian, announced the happy news that CCTV would be installed in our flat - she worked for CPHS (Camera Partnership for Home Safety) and had volunteered our place as a test bed.

The recoper was Mohammed Aswar MacDoogal and, as I wrote his biography on Wikibio, Memtech, never revealing their true purpose, paid Eugov for my expertise. Like every European citizen I was a state employee but, being leased to a private company and actually generating wealth, I was also a 'societal asset', which meant filing notice of all my movements and workrelated activities a week beforehand. This was heartbreaking, as I'd been about to suggest to Gillian that we escape to North Africa on one of the refugee boats. It never occurred to me that there might be a connection between my work and the CPHS cameras in our flat.

MacDoogal was a notorious libertarian blogger whose attacks on the formation of Eugov caused much chagrin in Notting Hill champagne and socialism circles. He was born to a Calvinist Scottish father and an Islamic Pakistani mother and in public claimed to be a Sikh - although privately he admitted this was so he could carry a dagger and didn't have to wear a crash helmet when thrashing his $1,000 \mathrm{cc}$ antique Ducati motorbike about the Highlands. He started his blog 'Invisible Worm' in 2008 with an article dissecting the then $€ 1$.2-billion cost of the British Olympics. Over the ensuing 20 years he wrote more than 8 million words, created numerous animations, short films and video news reports, in all of which he never revealed his identity. His blog is huge, and even now I have not seen all of it, for its thousands of distracting hyperlinks make this a nearimpossible task.

Working for Memtech I became hugely frustrated by the byzantine Diversity and Equality regulation, which had become suffocating after I wrote MacDoogal's biography. But Memtech, which we now know was a front for American-financed revolutionary group Free Europe, wanted the truth about MacDoogal, and risked telling me their true aim.

from a Eugov database: the frequent reports Gillian sent to her masters.

I was horrified by the betrayal, but when I got home I said nothing and just watched Gillian carefully. I could not grasp that her smiling manner and loving attentiveness were utterly false, and that I had never been able to see what lay behind them.

MacDoogal was one of the last and most effective political bloggers Europol managed to track down. They sent him to the Milton Keynes indoctrination camps and, like so many sent there, he was never heard from again. On my final visit to Memtech, Jansen revealed that they had cracked another Eugov database and hit the MacDoogal motherlode: hundreds of thousands of private e-mails, psyche and DNA profiles, tens of thousands of images. This, it turned out, was sufficient information to create a recoper: a reconstituted personality.

Read a book, especially nonfiction, and you'll know something about the author. Opinion pieces, as found in blogs, will tell you more. Further detail can be gleaned from the author's responses to others, and from his diaries and from film of him. And much of the organic structure of his brain can be reconstructed from his DNA. Utilizing all of this,

I loved the idea and obliged them by first providing the insipid and politically correct version, which I transmitted via e-mail, next providing the real deal, which I put on a memchip and took directly to their office in Hastings. Foolishly, I told Gillian about this subterfuge and, on a subsequent visit to Memtech, Jansen apprised me of the reality.

"Once we've got all we need we'll run the recoper and transmit it all out-state, and MacDoogal will soon be a thorn in Eugov's side again," he said. "Then, of course, we'll have to get out."

"I do have a wife," I told him.

"Yes," he said, "the one who had Home Safety CCTV installed to keep watch on you, and who is responsible for the beady-eyed characters sitting in hydrocars outside. The one who was working for Europol before she married you ... before she was instructed to keep a very close eye on a lonely nerd who'd had access to too much dangerous information..." Then he showed me evidence stolen
Memtech used programs of bewildering complexity, programs that could even make the distinction between irony and sarcasm, to build a model of MacDoogal's functioning mind, then kicked the whole construct into motion in a quantum synaptic computer. He began blogging again, right there on the screen in the Memtech offices, soon tearing into Eugov's every madness.

After Gillian's betrayal I knew I would not long have escaped the camps, and so via a long-prepared secret route, I joined the Memtech staff as they boarded a stealth boat from the Hastings shingle. Some days later when that boat finally slowed beside a jetty in Rabat harbour, I considered how, when reading MacDoogal's blog, one could not know that it was not written by a human being, but then, after my experience with Gillian, who was I to judge façades?

Neal Asher is now on his fourth three-book contract with Macmillan, is translated into ten languages, and reckons he's doing $O K$. His latest, Line War, will be out mid-2008. 